\title{
Diseases of different aetiologies in salmonids in Ukraine
}

\author{
Natalia Matvienko*, \\ Maria Maistrenko, \\ Leonid Buchatsky, \\ Alexander Didenko \\ Institute of Fisheries, \\ National Academy \\ of Agricultural Sciences, \\ 135 Obukhivska St., \\ Kyiv 03164, Ukraine
}

The paper contains the results of the studies into the ichthyopathological situation of the invasion and infectious diseases of salmonids carried out by the Ichthyopathology Laboratory of the Institute of Fisheries of Ukraine from 2013 to 2016. The investigated salmonid species included: the rainbow trout Oncorhynchus mykiss, the brown trout Salmo trutta morpha fario, the brook trout Salvelinus fontinalis, and the European grayling Thymallus thymallus. The fish were sampled from aquatculture farms as well as natural water bodies and their diseases included invasive (parasitic) and infectious (viral and bacterial). The most frequently encountered invasions in the brown and brook trout were ciliates: Chilodonella piscicola and Apiosoma conicum, Trichodina (in particular T. truttae and T. nigra), Ichtyophthirius multifiliis; monogenea Gyrodactylus birmani, and diplostoma Diplostomum spathaceum. Aeromonas and Flavobacterium bacteria were isolated from fry and young-of-the-year rainbow trout and brook trout. Y. ruckeri positive samples were isolated from the fish with the signs of yersiniosis. As for viral diseases, IPNV isolates (the first time in Ukraine) of the rainbow trout were first isolated in fish farms in the western regions of Ukraine. A phylogenetic analysis of these IPNV isolates was performed, which showed that they belonged to Sp strain and the European genotype.

Keywords: parasites, bacteria, viruses, salmonids, Ukraine

\section{INTRODUCTION}

Aquaculture is one of the fastest growing food production sectors in the world. Fast growth of this sector is first of all due to significant decline in wild fish stocks and exploitation of freshwater aquatic resources. Trout culture is becoming an impor-

\footnotetext{
*Corresponding author. Email: matvienko@if.org.ua, mnarine73@ukr.net
}

tant component of inland aquaculture in Ukraine. A number of salmonids such as the rainbow trout (Oncorhynchus mykiss), the brown trout (Salmo trutta morpha fario), and the brook trout (Salvelinus fontinalis) are currently reared in artificial conditions in Ukraine. Special attention is given to the restoration of the European grayling (Thymallus thymallus) in natural water bodies of the western regions of Ukraine. Therefore, the situation pertaining to the diseases of these species requires 
urgent measures. About 130,000 tons of trout are produced in Ukraine every year. Intensification of the processes of artificial fish production lead to the emergence of new diseases that cause significant losses to aquaculture (Buchatsky, 1994; FAO, 2006). Last year, due to large-scale importation of fish and other aquatic animals from different geographical zones, new diseases emerged, which had never been observed on the territory of Ukraine. Timely parasitological control, accurate determination of pathogens and the damages they cause caused in fish allow not only avoiding unfounded concerns regarding fish quality but also drawing attention to the infestation, which can be a cause for the rejection of fish or products manufactured of such fish by the consumers. The organization of the parasitological control during commercial rearing of fish should be given equal attention, because it is neither possible to prevent an outbreak of one or another disease nor to fight its manifestations without skilful orientation in the field of parasitology and pathology of the reared fish species (Davidov et al., 2009).

The parasite fauna of fish is very rich and diverse and the studies into fish parasites have been conducted in many countries. The parasites of salmonids reared at European pond farms are represented by Gyrodactylus derjavini, G. salaris, G. schulmani, Eubothrium crassum, Triaenophorus nodulosus, Proteocephalus sp., Phyllodistomum simile, Diplostomum spathaceum, D. paraspathaceum, D. chromatophorum, Tylodelphus clavata, Ichthyocotylurus variegates, I. platycephalus, Capillaria salvelini, Acanthocephalus lucii, A. anguillae, Argulus foliaceus, Hexamita salmonis, Ichthyobodo necator, Ichthyophthirius multifiliis, Apiosoma sp., Epistylis sp., Trichodina nigra, T. Mutabilis Trichodina nigra, T. mutabilis, T. fultoni, Trichodinella epizootica, and Ichthyophonus sp. (Amin, 1987; Lom, Dykova, 1992; Boeger et al., 1993; Buchmann et al., 1995; Moravec, 1998; Gibson et al., 2002). In Ukraine, the parasites of salmonids reared in pond fish farms and those inhabiting natural water bodies were investigated occasionally, therefore there is a need to study them and find the patterns of their development.
Bacteria often cause diseases and even fish mass mortality when culturing salmonid species. For example, in the last decade, streptococcus infections caused by specific strains of Streptococcus sp. in freshwater and sea fish became the main problem in aquaculture farms in many countries. The first outbreak of streptococcosis was recorded in 1958 in the rainbow trout in a commercial farm in Japan and later it was observed in many fish species, including the Atlantic salmon, the yellowtail, and the flatfish in Australia, England, Israel, Spain, Italy, Saudi Arabia, and South Africa (Austin, Austin, 1993; Gill et al., 2000).

Special attention should be given to fish diseases caused by viruses that have not been sufficiently studied. Because of the potential threat of the spread of viral diseases and cases of high mortality among salmonids at Ukrainian fish farms, there is a need in the investigation of the biological peculiarities of viral pathogens in fish and their effects on fish organisms. An analysis of the ichthyopathological situation at salmonid fish farms and in natural water bodies showed that infectious pancreatic necrosis (IPN) became a common problem. The causative pathogen of IPN is Aquabirnavirus of Birnaviridae family. More frequently this virus affects salmonid fingerlings and the young-ofthe-year, and mortality can reach 70\% (Golovina et al., 2003; Crane, Williams, 2008).

The aim of this study was to investigate major parasitic and infectious diseases of salmonids including the rainbow trout, the brown trout, the brook trout, and the European grayling in natural water bodies and aquaculture farms of Ukraine.

\section{MATERIALS AND METHODS}

\section{Parasitological methods}

Parasitological studies were carried out from March to November, from 2013 to 2016. We investigated the young-of-the-year and age-1 rainbow trout, the brook trout, and the brown trout from aquaculture farms of the Transcarpathian region of Ukraine. In total, 100 fish of each age group of each species were examined 
visually, and ten of each was taken for autopsy. We also examined the European grayling from natural water bodies: the middle reaches of the Krasna, the Brusturianka, the Mokrianka, and the Teresva rivers. In total, 20 European grayling of age- 1 and age- 2 each were examined visually and ten were taken for autopsy.

Fish were analysed according to Bykhovsky-Pavlovska (1985), including: (1) visual examination, (2) microscopic examination of scrapings from the body surface, fins, and gills, (3) misroscopic examination of eye lens, (4) excisions of skin and muscular tissue, (5) postmortem examination, search for parasites in abdominal cavity, (6) compression microscopy of internal organs and muscular tissue, (7) dissection of intestine, and (8) microscopy of gall bladder and swim bladder.

Fish age was determined on the basis of length-weight parameters and using scales. Parasites were identified using "Keys to the identification of the parasites of freshwater fish" (Bauer, 1987).

\section{Microbiological methods}

Microbiological studies were performed at several steps:

- primary inoculation of the material on tryptose-soy agar (TSA), which was incubated at a thermostat at a temperature of $26^{\circ} \mathrm{C}$ for $24 \mathrm{~h}$;

- pure cultures of microorganisms were produced by their inoculation on TSA. Morphological properties were determined according to Musselius (1983);

- determination of DNase activity of the isolated strains was performed on DNA agar.

The following step was to determine cultural, morphological, and biochemical properties of bacteria. Identification was performed according to the requirements of Bergey's Manual of Systematic Bacteriology (1994). Pathogenicity of bacteria isolated from the affected fish was studied using the biotest method on clinically healthy fish by reproducing the disease model.

Concurrently with the biochemical analysis of isolated aeromonads, we performed identification of the isolated Aeromonas strains with the use of standardized test-system API 20E
(BioMerieux, France) designed for the identification of gram-negative bacilli based on 21 biochemical reactions.

\section{Molecular virological methods}

Polymerase chain reaction (PCR) was performed with the aid of the "AmpliSens 200-1" kit ("AmpliSens", Russia). For the detection of infectious pancreatic necrosis virus, we used two pairs of different primers and an optimization of the reaction was performed.

Pair I - oligonucleotide primers flanking fragments of the VP2 protein gene sequence. The original oligonucleotide primers had the following sequence: F 5'-ATGAATTCGAACCCCCAGGA-3' and R 5'-GCGAATTCTGATTGGTCTGA-3'. The temperature profile of the reaction was as follows: cycle 1 at $95^{\circ} \mathrm{C}$ for 3 minutes; cycle 2:denaturation at $95^{\circ} \mathrm{C}$ for $30 \mathrm{~s}$, annealing of primers at $62^{\circ} \mathrm{C}$ for $30 \mathrm{~s}$, elongation at $72^{\circ} \mathrm{C}$ for $60 \mathrm{~s}$; cycle 2 is repeated 40 times; cycle 3 - at $72^{\circ} \mathrm{C}$ for $7 \mathrm{~min}$. The size of the amplified DNA fragment was $620 \mathrm{bp}$.

Pair II - oligonucleotide primers specific for the nucleoprotein (NS) gene, followed by the sequence $\mathrm{F}$ 5'-AAAGCCATAGCCCATGAAC- $3^{\prime}$ and R 5'-TCTCATCAGCTGGCCCAGCTAC-3'. The temperature profile of the reaction: cycle 1at $95^{\circ} \mathrm{C}$ for 4 minutes; cycle 2 : denaturation at $94^{\circ} \mathrm{C}$ for $30 \mathrm{~s}$, annealing of primers at $60^{\circ} \mathrm{C}$ for $30 \mathrm{~s}$, elongation at $72^{\circ} \mathrm{C}$ for $60 \mathrm{~s}$; cycle 2 is repeated 35 times; cycle 3 at $72^{\circ} \mathrm{C}$ for $7 \mathrm{~min}$. The size of the amplified DNA fragment is $204 \mathrm{bp}$.

Analysis of amplification products was performed by electrophoresis in $2 \%$ agarose gel with the use of standard markers Gene Ruller $100 \mathrm{bp}$ DNA Ladder plus (ThermoScientific, USA).

Sequencing of purified amplified fragments was performed on Applied Biosystems 3730xl DNA Analyzer with the use of Big Dye terminators, version 3.1 (Applied Biosystems, USA). Identification and comparison of the obtained sequences was performed with the aid of BLAST analysis (http://www.ncbi. nlm.him.gov). Phylogenetic analysis was performed with the aid of PHYLIP (Felsenstein, Kishimo, 1993) and DNA-Star, MEGA 5 (Tamura et al., 2011) packages. The reliability of 
the constructed trees was checked with bootstrap with 1000 bootstrap replications (Felsenstein, Kishimo, 1993). Phylogenetic trees were built by the neighbour-joining method (Saitou, Nei, 1987) and maximum likelihood (ML) (Huelsenbeck, Crandall, 1997).

\section{RESULTS}

\section{Parasitological studies}

It was found that in Ukraine, salmonids are more prone to infections in aquaculture conditions that are often due to their high stocking densities. The parasite fauna of salmonids in Ukraine is represented by ten species (Table 1).

We detected that the rainbow trout, the brown trout, and the brook trout were infested with the following ciliates: Chilodonella piscicola, Apiosoma conicum, Trichodina, truttae, and T. nigra, Ichtyophthirius multifiliis, which were localized on fish body surface, fins, and gills. Gyrodactylus birmani were found on trout body surface and gills with invasion intensity of 5 to 10 parasites per fish of less than $20 \mathrm{~g}$ with up to $90 \%$ prevalence in all studied fish. External examination of adult trouts (rainbow trout, Oncorhynchus mykiss) showed the signs of infesation with Diplostomum spathaceum with low prevalence indices. Leeches Piscicola geometra were found in rainbow, brown, and brook trout. They were observed on the skin, gills, and in nasal and oral cavities of age-1 and age-2 fish. No leeches were found in juvenile fish.

Cystidicolosis isan invasive disease of salmonids caused by the nematode Cystidicola farionis from Rhabdochonidae family. It was the only parasite found in the European grayling (age-2) in Ukraine. This nematode was located in the swim bladder (Fig. 1)

\section{Microbiological studies}

As for the bacterial diseases, Aeromonas were the most common in the isolated samples of fingerlings and young-of-the-year rainbow and brook trout. Aeromonas strains were mostly A. salmonicida. Pseudomonas, Flavobacterium, and Yersinia were sometimes found in O. mykiss, S. trutta morpha fario, and S. fontinalis. Positive Yersinia ruckeri samples were taken from the fish affected with the signs of yersiniosis infection. The gills of the infected fish were characterized by necrotic inflammation on skin, and haemorrhages were observed near fins (Fig. 2). Among the total amount of isolated bacteria, Pseudomonas composed $15-20 \%$ in juveniles and $10-15 \%$ in older-age groups of fish. Aeromonas were found in $12-18 \%$ in juveniles and $16-20 \%$ in older-age groups. Flavobacteria dominated (7-10\%) in older-age groups of fish. All bacteria species were found mainly in the fish with clinical signs of bacterial diseases.

Table 1. Prevalence of salmonid parasites in Ukraine $(\boldsymbol{n}=\mathbf{1 0})$

\begin{tabular}{ccccc}
\hline & $\begin{array}{c}\text { Oncorhynchus } \\
\text { mykiss }\end{array}$ & $\begin{array}{c}\text { Salvelinus } \\
\text { fontinalis }\end{array}$ & $\begin{array}{c}\text { Salmo trutta } \\
\text { morpho fario }\end{array}$ & $\begin{array}{c}\text { Thymallus } \\
\text { thymallus }\end{array}$ \\
\hline Hexamita truttae & $10 / 6$ & $5 / 3$ & - & - \\
\hline Apiosoma sp. & $20 / 15$ & $15 / 8$ & $12 / 6$ & - \\
\hline Trichodina nacuta & $18 / 9$ & $12 / 7$ & - & - \\
\hline Trichodina truttae & $16 / 5$ & $10 / 7$ & $5 / 3$ & carriage \\
\hline Ichtyophthirius multifilis & $25 / 11$ & $22 / 9$ & $2 /-$ & - \\
\hline Gyrodactylus salaris & $18 / 8$ & $16 / 9$ & $9 / 4$ & - \\
\hline Diplostomum spathaceum & $9 / 5$ & $15 / 8$ & $5 / 3$ & - \\
\hline Cystidicola farionis & - & - & - & - \\
\hline Ergasilus sieboldi & $12 / 7$ & $14 / 6$ & $10 / 4$ & - \\
\hline Argulus faliaceus & $3 / 2$ & carriage & & - \\
\hline
\end{tabular}

Note: numerator - prevalence, \%; denominator - abundance index, ind. “-” not detected. 


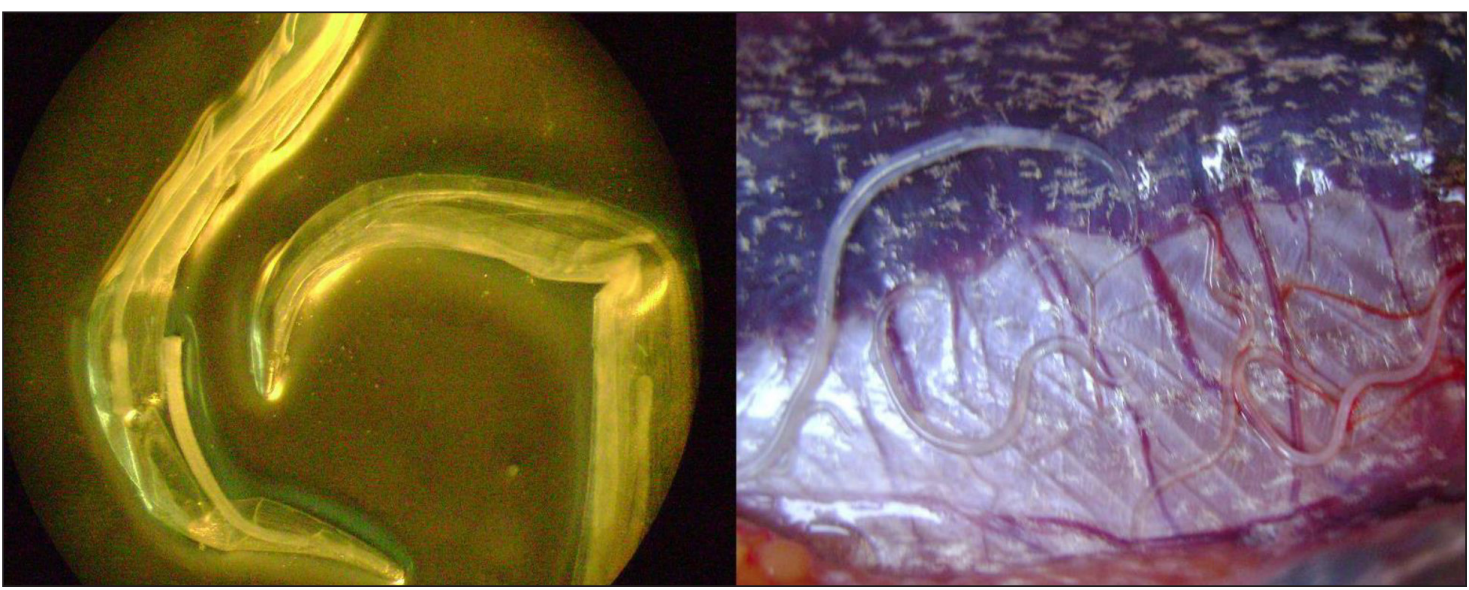

Fig. 1. Cystidicola farionis (family Rhabdochonidae) in the swim bladder of the European grayling (photo by the author)

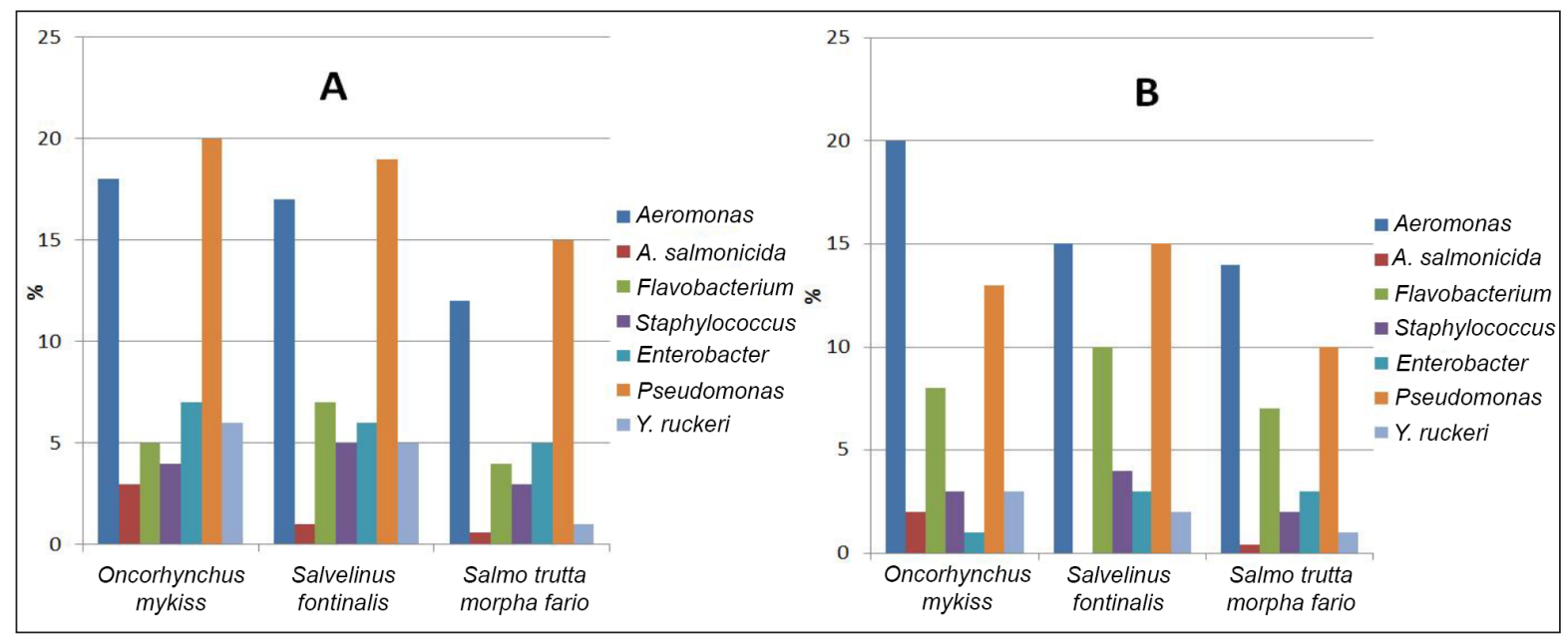

Fig. 2. Occurrence of bacteria in different salmonid species: A - juveniles; B - adult fish

\section{Phylogenetical analysis of Ukrainian IPNV isolates}

As for viral diseases, IPNV isolates of the rainbow trout were first isolated in fish farms of western regions of Ukraine (Volyn, Lviv, Transcarpathian, Chernivtsi regions). Because these diseases are the most dangerous for salmonids, they received more attention in our study.

One of the steps of our work was to conduct a phylogenetic analysis to determine the origin of Ukrainian viral isolates. The nucleotide sequences of the capside protein of two IPNV isolates were sequenced and compared (Table 2). It showed that the isolated and analysed Ukrain- ian isolates of IPNV belong to the same strain. However, these results did not give an answer to the question regarding the strain that these Ukrainian isolates belong to.

Hence, the next step of our work was to compare the nucleotide sequences of Ukrainian isolates with nucleotide sequences of IPNV strains and isolates from world data bases. The Ukrainian isolates were referred to as serogroup A strain Sp. The results of phylogenetic studies showed that IPNV isolatescirculating on the territory of Ukraine were genetically close or had a common ancestor with the viruses of strain $\mathrm{Sp}$ and, along with other representatives, formed a large genogroup A (Fig. 3). 
Table 2. Assessment of the similarity of Ukrainian isolates of infectious pancreatic necrosis virus (IPNV) with GenBank isolates based on nucleotide and amino acid sequences

\begin{tabular}{c|c|c|c|c|c|c}
\hline \multirow{2}{*}{$\begin{array}{c}\text { Number in } \\
\text { GenBank }\end{array}$} & \multirow{2}{*}{ Country } & \multirow{2}{*}{ Strain } & \multicolumn{2}{c|}{$\begin{array}{c}\text { \% of similarity of nucleo- } \\
\text { tide sequences }\end{array}$} & \multicolumn{2}{c}{$\begin{array}{c}\text { \% of similarity of amino } \\
\text { acid sequences }\end{array}$} \\
\cline { 4 - 7 } & & & Ukr 1 & Ukr 2 & Ukr 1 & Ukr 2 \\
\hline HQ383920.1 & Iran & IRFIPN07 & 79.3 & 79.7 & 79.7 & 80.2 \\
\hline EF493156.1 & Spain & Sp & 39.9 & 39.8 & 40.2 & 40.5 \\
\hline \multirow{2}{*}{ AF342729.1 } & Croatia & $\begin{array}{c}\text { serotypeA2 } \\
\text { isolate“BHD/05 }\end{array}$ & 39.2 & 39.8 & 39.6 & 39.9 \\
\hline \multirow{2}{*}{ HQ833318.1 } & Norway & $\begin{array}{c}\text { S-IPNV/FS2- } \\
\text { 01" }\end{array}$ & 39.7 & 39.9 & 39.9 & 40.1 \\
\hline AF342727.1 & USA & West Buxton & 39.9 & 40.1 & 39.9 & 40.0 \\
\hline KF536961.1 & Korea & Kor-EYC02 & 41.8 & 42.4 & 41.9 & 42.0 \\
\hline AJ622823.1 & France & Strain 31-75 & 31.6 & 32.3 & 32.2 & 33.1 \\
\hline AF342732.1 & Canada & Canada 1 & 39.1 & 39.7 & 39.8 & 39.9 \\
\hline
\end{tabular}

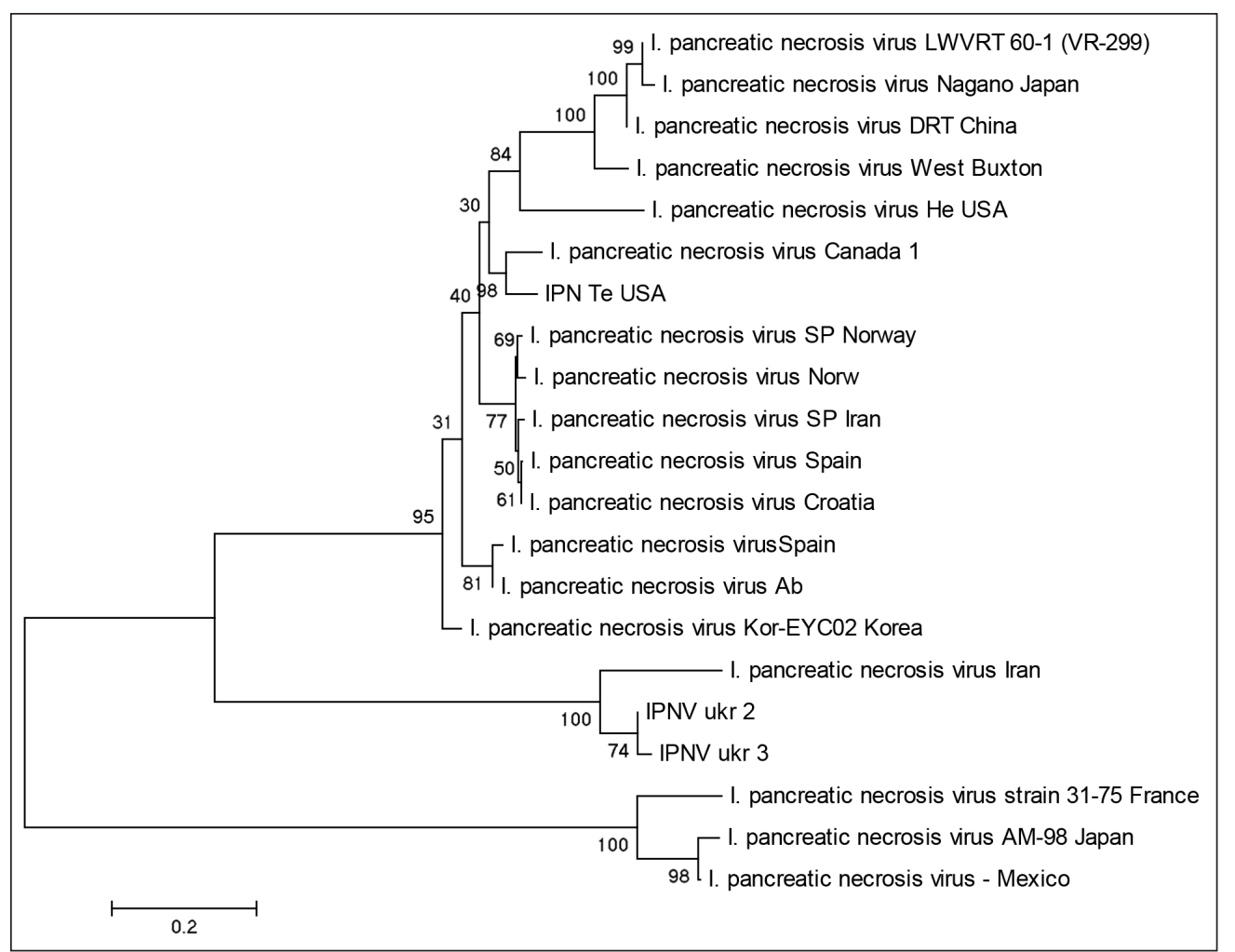

Fig. 3. Evolutionary relationships between Ukrainian isolates and known IPNV isolates from GenBank based on nucleotide sequences (neighbour-joining method)

\section{DISCUSSION}

The diversity of the parasitic fauna of salmonids in Ukraine is not very rich. The parasites of different salmonid species are very similar and the composition of dominant species is almost the same. Moreover, quantitative parameters of infestation show a strong resemblance, although with some differences. All this indicates that these fish species are close 
both in the systematic and the ecological aspects. It must be stressed that ectoparasites predominate in trout. The parasite fauna of adult fish is richer than that of the juveniles.

In Ukraine, parasitic diseases in salmonids are registered more frequently in spring and summer periods. This is due to optimum meteorological and hydrophysical conditions (in particular water and air temperature) for the development and reproduction of parasites during these seasons. A pronounced seasonality of diplopstomiasis can be explained by the active reproduction of the intermediate hosts (molluscs and copepods) during these periods as well as migrations of the definitive hosts (waterfowl) in spring. Ciliates were found mainly in winter that can be explained by the reduced resistance of fish organism during this period.

According to the literature data (Mitenev, Shulman, 1984; Gun'kovskiy, 1991; Pronin, Burdukovskaya, 2014), in Ukraine, specific parasites of the wild European grayling include seven species. Most of them are the species the intermediate hosts of which are benthic and zooplanktonic organisms. The most frequent are Tylodelphys clavata, I. erraticus. Fish become infected with the trematodes Phyllodistomum folium, Ph. conostomum when they swallow secondary sporocysts with metacercariae (Pronin, Burdukovskaya, 2014). More frequent are the parasites the development of which is associated with zoobenthos. Parasites developing with the participation of zooplankton are observed in the European grayling rarer and in small quantities (Mitenev, Shulman, 1984).

The European grayling is characterized by age-related peculiarities of parasite infestations (Mitenev, Shulman, 2005). During the first year of life, it has parasites the larval stages of which actively penetrate the host, and at the age of three and four years, it can contain helminths, the infestation with which is associated with its ingestion of intermediate hosts (Bylund, Pugachev, 1989).

Among the detected bacterial pathogens, A. salmonicida, a causative agent of furunculosis, is the most dangerous for salmonids. Other discovered microorganisms belong to poten- tially pathogenic microflora because they can potentially cause specific and associative bacterioses in fish under stress conditions. Motile aeromonads such as A. hydrophila, A. sobria, and A. caviae are officially recognized as epizootically important bacteria for fish (Timur, Timur 1991; Austin, Austin, 2007).

Flavobacteria did not virtually pose a threat for salmonids in the wild but their role becomes important in the pathology and mortality of juvenile salmonids when rearing fish in aquaculture conditions.

Pseudomonas are a common species of aquatic microflora. Along with aeromoands, this is the most widespread genus of bacteria that composes the bacteriocenoses of salmonids in Ukraine. They were detected every year in apparently healthy fish and in those with signs of pathology in all examined water bodies.

As a rule, Staphylococcus and Enterobacter are indicators of biological contamination of water bodies. They are spread in water only by warm-blooded animals and humans, but they are able to participate in unspecific septic processes in fish and cause various bacterioses (Austin, Austin, 1993). Fish diseases caused by $S$. epidermidis are characterized by exophthalmos and ulcerative lesions on the tail $(\mathrm{Ku}-$ suda, Sugiyama, 1981). Similar pathological symptoms and accumulation of ascitic fluid in the abdominal cavity caused by $S$. warneri were reported in the rainbow trout (Gil et al., 2000). There are also diseases caused by S. liquefaciens. The pathogen was found in fish that died without any signs of pathology but an autopsy showed swollen kidneys and spleen, marbled coloration of the liver, and accumulation of ascitic fluid in the abdominal cavity (Austin, Austin, 1999). S. liquefaciens were isolated from brook trout with signs of septicaemia in the USA in 1999. The fish was characterized by anus redness, multiple haemorrhages in internal organs, and accumulation of ascitic fluid (Starliper, 2001). During our studies, no symptoms of diseases were detected in salmonids infected with these microorganisms. Probably low water temperatures in the examined water bodies inhibit the development of pathological 
processes because the optimum temperature for the development of these bacteria is 15$20^{\circ} \mathrm{C}$ (Austin et al., 1995).

As it is known, IPNV is one of the typical species of the genus Aquabirnavirus, moreover, according to the available data (Mahy, Kango, 1996), this viral species has a large number of strains and is phylogenetically related to the other Aquabirnavirus species. When comparing the cDNA nucleotide sequence segments of VP2 capside protein of IPNV isolates with each other, the homology is $98-99 \%$. According to the literature data (Cutrine et al., 2000), if the homology of viral nucleotide sequences is $95 \%$ and more, they are the isolates of one strain, if less than $90 \%$, then they are different strains of one virus.

Taking into account that Ukrainian isolates are genetically close to those circulating in Iran, we can trace the geographic distribution of this causative agent. Migrations of infected fish, shipping of infected eggs and fish contribute to the spread of the virus inside and outside of the country. The studies of ichthyopathological situation in aquaculture farms and natural water bodies allow obtaining information and predicting the situation of possible outbreaks of viral infections.

Results of our studies as well as the presence of this sequence in the database of the segment A genome will be useful for further studies of aquatic viruses and for the development of diagnostic programmess for controlling fish diseases. This is a relatively fast and cost-effective method compared to the isolation of a virus in cell cultures Invasive (parasitic) and infectious (viral and bacterial) diseases affected salmonids such as the rainbow trout, the brown trout, and the brook trout from aquaculture farms of Ukraine and the European grayling from natural water bodies. The most frequently encountered invasions in these fish species were caused by ectoparasites, which were localized on fish body surface, fins, and gills. The European grayling in Transcarpathian rivers was affected by nematoda C. farionis. As for infectious diseases, Aeromonas hidrophila, Aeromonas salmonicida, and Flavobacterium psychrophilum bacteria were isolated from fry and young-of-the-year rainbow and the brook trout. In the case of viral diseases, IPNV isolates of the rainbow trout were first isolated in fish farms in the western regions of Ukraine. Phylogenetic studies showed that IPNV isolates circulating on the territory of Ukraine belonged to the European genotype.

Received 17 December 2018 Accepted 15 April 2019

\section{References}

1. Amin OM. Key to the families and subfamilies of Acanthocephala, with the erection of a new class (Polyacanthocephala) and a new order (Polyacanthorhynchida). J Parasitol. 1987; 73: 1216-9.

2. Austin B, Austin DA. Aerornonadaceae representatives (Aeromonas salmonicida). In: B. Austin and DA Austin. Bacterial Fish Pathogens: Disease of Farmed and Wild Fish. Chichester: Ellis Horwood Ltd; 1993a. p. 86-170.

3. Austin B, Austin DA. Bacterial fish pathogens: disease in farmed and wild fish. New York: Ellis Horwood Ltd; 1993b. 384 p.

4. Austin B, Austin DA. Bacterial fish pathogens disease of farmed and wild fish. 3rd ed. Springer-Praxis, Chichester, UK; 1999. 457 p.

5. Austin B, Austin DA. Bacterial fish pathogens: disease in farmed and wild fish. 4th ed. Praxis Publishing, Chichester, UK; 2007. 384 p.

6. Austin B, Stuckey LF, Robertson PAW, Effendi I, Griffith DR. A probiotic strain of Vibrio alginolyticus effective in reducing diseases caused by Aeromonas salmonicida, Vibrio anguillarum and Vibrio ordalii. J Fish Dis. 1995; 18: 93-6.

7. Bauer ON. Opredelitel' parazitov presnovodnykh ryb fauny SSSR. Vol. 3. Nauka, Leningrad; 1987.583 p. Russian.

8. Boeger WA, Kritsky DC. Phylogeny a revised classification of the Monogenoidea 
Bychowsky, 1937 (Platyhelminthes). Syst Parasitol. 1993; 26: 1-32.

9. Buchmann K, Uldal A, Lyholt HC. Parasite infections in Danish trout farms. Acta Vet Scand. 1995; 36(3): 283-98.

10. Bykhovsky-Pavlovska IE. Parazity ryb. Rukovodstvo po izucheniyu. Leningrad: Nauka; 1985. 121 p. Russian.

11. Bylund G, Pugachev ON. Monogenea of fish in Finland (Dactylogyridae, Ancyrocephalidae, Tetraonchidae). Parasites of freshwater fishes of North-West Europe. Materials of International simposium. Petrozavodsk; 1989. p. 20-30.

12. Crane MStJ, Williams LM. Viruses of salmonids: Virus isolation in fish cell lines. Australia and New Zealand Standard Diagnostic Procedure; $2008.36 \mathrm{p}$.

13. Cutrín JM, Olveira JG, Barja JL, Dopazo CP. Diversity of infectious pancreatic necrosis virus strains isolated from fish, shellfish and reservoirs in Northwestern Spain. Appl Environ Microbiol. 2000; 66: 839-43.

14. FAO. State of world aquaculture 2006. Inland Water Resources and Aquaculture Service, Fishery Resources Division, Fisheries Department, FAO Fisheries Technical Paper. N. 500, 2006.

15. Felsenstein J, Kishino H. Is there something wrong with the bootstrap on phylogenies? A reply to Hillis and Bull. Syst Biol. 1993; 42: 193-200.

16. Gibson DI, Jones A, Bray RA. Keys to the Trematoda. CABI Publishing and the Natural History Museum, London. 2002; 1: $521 \mathrm{p}$.

17. Gill P, Vivas J, Gallardo CS, Rodriguez C. First isolation of Staphylococcus warneri from diseased rainbow trout Oncorhynchus mykiss (Walbaum), in Northwest Spain. J Fish Dis. 2000; 23(4): 295-8.

18. Golovina NA, Strelkov YA, Bauer ON, Voronin VN. Ikhtiopatologiya. Mir, Moscow; 2003. 448 p. Russian.
19. Gun'kovskiy SA. Gelminty lososevykh v rybovodnykh khozyaistvakh Ukrainy. Proceedeings of the scientific conference "Ecological-biological and faunistic aspects of helminthoses", Yerevan, Armenia; 1991. 34-5 p. Russian.

20. Huelsenbeck JP, Crandall KA. Phylogeny estimation and hypothesis testing using maximum likelihood. Annu Rev Ecol Syst. 1997; 28: 437-66.

21. Kusuda R, Sugiyama A. Studies on characters of Staphylococcus epidermidis isolated from diseased fishes, I. Fish Pathology. 1981; 16: $15-24$.

22. Lom J, Dyková I. Protozoan parasites of fishes. Developments in aquaculture and fisheries science. Amsterdam; New York, Elsevier. 1992; 26: $315 \mathrm{p}$.

23. Mahy BWJ, Kangro HO. Virology methods manual. London: Academic Press; 1996. 374 p.

24. Mitenev VK, Shulman BS. Ekologo-geograficheskij analiz parazitofauny Evropejskogo khariusa Thymallus thymallus (L.) Thymallidae $\mathrm{v}$ raznyh chastyah ego areala. Voprosy ikhtiologii. 1984; 24(5): 843-54.

25. Mitenev VK, Shulman BS. Parazitofauna khariusa Thymallus thymallus (L.) vodoyomov Kol'skogo regiona. In: Lososevidnye ryby Vostochnoi Fennoskandii. Petrozavodsk; 2005. 225 p. Russian.

26. Moravec F. Nematodes of freshwater fishes of the Neotropical Region. Praha: Academia; 1998. $464 \mathrm{p}$.

27. Musselius VA. Laboratornyi praktikum po boleznyam ryb. Moscow: Legkaya i pishchevaya promyshlennost'; 1983. 294 p. Russian.

28. Pronin NM, Burdukovskaya TG. O stabilnosti mnogoletnikh pokazateley zarazhennosti khariusovykh ryb ozera Baikal (Rossiya) i Khubsugul (Mongolia) paraziticheskoi kopepodoi Salmincola thymalli (Copepoda: Lernaeopodidae). Izvestiya Irkutskogo Gosudarstvennogo Universiteta, seriya "Biologia. Ekologia”. 2014; 8: 49-55. Russian. 
29. Saitou N, Nei M. The neighbor-joining method: A new method for reconstructing phylogenetic trees. Mol Biol Evol. 1987; 4: 406-25.

30. Starliper CE. The effect of depuration on transmission of Aeromonas salmonicida between the freshwater bivalve Amblema plicata and Arctic char. J Aquat Anim Health. 2001; 13: 56-62.

31. Tamura K, Peterson D, Peterson N, Stecher G, Nei M, Kumar S. MEGA5: molecular evolutionary genetics analysis using maximum likelihood, evolutionary distance, and maximum parsimony methods. Molec Biol Evol. 2011; 28: 2731-9.

32. Timur G, Timur M. An outbreak of enteric redmouth disease in farmed rainbow trout (Oncorhynchus mykiss) in Turkey. B Europ Assoc Fish Pat. 1991; 11: 181-2.
Natalia Matvienko, Maria Maistrenko, Leonid Buchatsky, Alexander Didenko

\section{SKIRTINGOS ETIOLOGIJOS LIGOS, APTIK- TOS LAŠIŠINĖSE ŽUVYSE UKRAINOJE}

\section{Santrauka}

Straipsnyje pateikiami lašišinių žuvų invazijos ir infekcinių ligų ichtiopatologinès situacijos tyrimų rezultatai, atlikti Ukrainos Žuvininkystès instituto Ichtiopatologijos laboratorijoje 2013-2016 metais. Tyrimui žuvys buvo paimtos iš žuvų veisyklų ir natūralių vandens telkinių. Ištirtos šios lašišinių žuvų rūšys: vaivorykštinis upètakis (Oncorhynchus mykiss), rudasis upetakis (Salmo trutta morpha fario), upokšninis šalvis (Salvelinus fontinalis) ir kiršlys (Thymallus thymallus); nustatytos invazinès (parazitinès) ir infekcinès (virusinès ir bakterinès) jų ligos. Dažniausios invazijos su mažais ekstensyvumo indeksais: blakstienotuju - Chilodonella piscicola ir Apiosoma conicum, Trichodina - T. truttae ir T. nigra bei Ichtyophthirius multifiliis, monogenèju - Gyrodactylus birmani, diplostomų - Diplostomum spathaceum. Kiršliuose rasta nematodų Cystidicola farionis (Rhabdochonidae šeima). Aeromonai ir flavobakterijos buvo nustatyti vaivorykštinių upėtakių ir kiršlių audiniuose. Teigiami Y. ruckeri mėginiai buvo išskirti iš žuvų, turinčių jersiniozès požymių. Vaivorykštinių upètakių IPNV izoliatai (pirmą kartą Ukrainoje) pirmiausia buvo išskirti vakarinių Ukrainos regionų žuvų veisyklose. Šių IPNV izoliatų filogenetinė analizė rodo, kad jie priklauso Sp kamienui ir Europos genotipui.

Raktažodžiai: parazitai, bakterijos, virusai, lašišinès žuvys, Ukraina 